\title{
Hizlanan Dünyaya Bir Alternatif Olarak Seferihisar Sakin Şehir Örneği
}

$*$

\author{
N. Beril Özer Tekin ${ }^{1}$ \\ ORCID: 0000-0002-1402-7891
}

Öz

Bu araştırmanın amacı, kapitalizmin içinde bulunduğu kriz ve çelişkilerin sonucu olarak geliştirilen yaklaşımlardan birisi olan sakin şehir hareketinin nasıl bir işleyişe sahip olduğunun ve sürdürülebilirliğinin Seferihisar örneğinde araştırılmasıdır. Araştırma problemi doğrultusunda "Sakin şehir hareketi Türkiye Seferihisar örneğinde sürdürülebilir ve alternatif bir kalkınma anlayışı sunar mı?" sorusuna yanıt aranmıştır. Araştırma, nitel ve nicel araştırma tekniklerinin bir arada kullanıldığı karma metodoloji esasına uygun olarak yürütülmüştür. Araştırma kapsamında yargısal örneklem yoluyla seçilen paydaş kuruluşlar ve yerel aktörlerden derinlemesine görüşme tekniği; oranlı tabakalı örnekleme yoluyla seçilen 332 kişiden ise yüz-yüze anket tekniği kullanılarak veri toplanmıştır. Nicel ve nitel veriler birbiriyle bütünleştirilerek, birbirini destekleyici nitelikte kullanılırken Neo-Marksist yaklaşım ışığında analiz edilmiştir. Araştırmanın sonucunda, ilçenin sakin şehir unvanını kazanmasıla birlikte gerçekleştirilen uygulamalarla sürdürülebilir kalkınma bă̆lamında önemli adımların atıldı̆̆g, belediyenin hizmetlerinde artış olduğu; ancak nüfus artışıyla birlikte ilçede büyük kentlerde görülen çarpık yapılaşma, soylulaşma, pahahılı̆̆ın artışı, yabancılaşma, gelir farklılıklarının artması gibi sorunların ortaya çıktı̆̆ı belirlenmiştir. Sonuç olarak, incelenen örnek bă̆lamında ilçe iyi uygulama örnekleri sunsa da hareketin sürdürülebilirliği konusunda engeller vardır.

Anahtar Kelimeler: Sakin şehir hareketi, kapitalizm, çeore krizi, sürdürülebilirlik, karma metodoloji.

\footnotetext{
${ }^{1}$ Dr.Öğr. Üyesi, Doğuş Üniversitesi, Fen Edebiyat Fakültesi, Sosyoloji Bölümü, E-posta: btekin@dogus.edu.tr idealkent @ Kent Araştırmaları Dergisi (Journal of Urban Studies) 


\title{
Case of Seferihisar As an Alternative to the Accelerating World
}

\author{
N. Beril Özer Tekin ${ }^{2}$ \\ ORCID: 0000-0002-1402-7891
}

\begin{abstract}
This research aims to investigate cittaslow movement, which developed as a result of crises and paradoxes, to open a new movement area and sustainability within the case of Seferihisar. The following question "Does the calm city movement offer a sustainable and alternative understanding of development in the case of Seferihisar in Turkey?" was investigated during the study. The research was conducted on the basis of a mixed methodology. In the scope of the research, in-depth interviews were held with the stakeholder institutions and local actors selected by purposive sampling; the questionnaire was applied face to face to 332 individuals selected by proportional stratified sampling from local people. Both qualitative and quantitative data were integrated during processing from the Neo-Marxist approach. As a result of the research, the services of the municipality increased, crucial improvement was provided in terms of sustainable development by the projects with the cittaslow title; however, with the increasing population, a number of problems such as urban sprawl, gentrification, increase in cost, alienation, increase in income differences have arisen. Finally, although the studied case provided good practices, there are obstacles in the sustainability of the cittaslow movement in the context of the case studied.
\end{abstract}

Keywords: Cittaslow movement, capitalism, environmental crisis, sustainability, mixed methods.

\footnotetext{
${ }^{2}$ Assist. Prof., DoğuşUniversity, Faculty of Artsand Sciences, Department of Sociology, E-mail:btekin@dogus.edu.tr idealkent @ Kent Araştırmaları Dergisi (Journal of Urban Studies) 


\section{Giriş $^{3}$}

Endüstriyel üretim biçimiyle birlikte giderek gelişen kapitalist ekonomik sistem içinde "hı", "zaman" ve "para" kavramları birbiriyle yakın bir ilişkide olmuştur. Modernliği inşa eden en önemli mihenk taşlarından birisi olarak "endüstriyalizme" karşllık gelen endüstriyel üretim süreci aşamalarında h1zın toplumsal olarak anlamı ve etkileri belirlenmiştir (Giddens, 1994). Yeni dönemdeki insanı ve toplumları geçmiştekilerden farklı kılan en önemli unsurlar ise "hı"la birlikte "geçicilik" olmuştur (Toffler, 2006).

Tarihsel süreç içinde kapitalizmin küreselleşmesi ve Neoliberal politikaların benimsenmesi sonucu ekonomi ve siyasetle birlikte kentlerde de önemli dönüşümler görülmüştür (Baybars ve Güzeloğlu, 2015; Merrifield, 2012; Üstündağll, Semmens ve Freeman, 2012). Dünyanın büyük çoğunluğunun yanı sıra Türkiye'nin de benimsediği neoliberal politikalarla birlikte devlet kamu hizmetlerinden büyük ölçüde çekilirken, şirketleri ve geliştirici yatırımları özel sermayeye bırakmıştır. Böylece Merrifield (2012)'in de belirttiği gibi ticaret ve sermaye kente güçlü bir şekilde yerleşmiştir. Özellikle 1980'li yıllardan itibaren köyden kente artan göç, kentlerde nüfus artışı ile birlikte çarpık yapılaşma gibi sonuçları ortaya çıkarmıştır.

Kentsel alanda dev inşaat şirketleri kent mekanını rant elde edecek şekilde yeniden yapılandırırken, mekanda yıllardır yaşamını sürdüren yerel halklar ise yersiz yurtsuzlaşmaktadır. İşleyişte olan, hâkim kalkınma paradigmasının yerel ölçekte ne sürdürülebilir, ne de tatmin edici olan sonuçlar ortaya çıkartması ve bu sorunların kentlere yansıması sonucu sakin şehirler alternatif bir yaklaşım olarak ortaya çıkmıştır.

Sakin şehir hareketi kapitalizmin içinde bulunduğu kriz ve çelişkilerin sonucu olarak ortaya konulan yaklaşımlardan birisidir. Alandaki çalışmaların "sürdürülebilir kalkınma", "şehir planı", "turizm” ve "mimari" gibi konulara yoğunlaşmış durumda olduğu; sakin şehir kavramının çoğunlukla "yerel kalkınma" ve "sürdürülebilir turizm"e odaklı olarak ele alındığı ve çoğunluğunun derleme çalışmalardan oluştuğu görülmektedir (Hekimci, 2014; Keskin, 2012; Mutdoğan, 2015; Radstorm, 2011; Sırım, 2012; Sungur, 2013; Şahinkaya, 2010; Şahin ve Kutlu, 2014).

\footnotetext{
${ }^{3}$ Makale “Türkiye'de Kapitalizmin İşleyişi Sürecinde Sakin Şehir Hareketi ve Sürdürülebilirlik: Seferihisar Örneği" (Tez No: 529760) başlıklı doktora tezinden türetilmiştir. Araştırma IX. Ulusal Sosyoloji Kongresi (19-21 Eylül, 2019, Ankara) ve 14 ${ }^{\text {th }}$ Conference of the European Sociological Association'da (20-24 Ağustos 2019, Manchester) sunulmuş; bildiri metni yayınlanmıştır.
} 
İlçe, yerel kalkınmanın bir parçası olarak turizm ile sakin şehre özgü kriterlerin karşı karşıya geldiği bir konumda olması nedeniyle tercih edilmiştir. Antropolog Thomas Eriksen (2001) "küçük yerlerin çalışılmasıyla büyük meselelerin analiz edilebileceğini" vurgularken; Bell ve Jayne (2006) ise kent çalışmalarında küçük yerleşimlerin az çalışılmasını "küçük şehirlerin dertli ihmali" olarak nitelendirmektedir.

$\mathrm{Bu}$ araştırma kapsamında sakin şehir hareketinin mevcut ekonomik sistemdeki sürdürülebilirliğini analiz etmeye yönelik karma yöntemin uygulandığı, sahadaki çeşitli paydaşları kapsayacak, çatışma ve çelişkileri ortaya koyacak, farklı paydaşların dâhil edildiği nitelikte alana katkı sağlaması amaçlanan bir araştırma yapılmıştır. Bu araştırmanın problemi doğrultusunda "Sakin şehir hareketi Türkiye Seferihisar örneğinde sürdürülebilir ve alternatif bir kalkınma anlayışı sunar mı?" sorusuna yanıt aranmıştır:

\section{Kavramsal Çerçeve}

\section{Yavaş Hareketi ve Sakin Şehir Kavramı}

Üretim rejimleri ve tüketim ile yakından ilişkili olan kapitalist ekonomik işleyişin ve gündelik hayatın dinamiği olarak önemli bir toplumsal norm haline gelen "hız" kavramı 21. yüzyılda sorgulanmaktadır (Honore, 2008; Kundera, 1996; Sayar, 2018; Steele, 2012; Virgilio, 1998). Son 30 yıllık zaman dilimi içinde hıza bir alternatif olarak verimlilik esasının önemine vurgu yapan bir felsefe olarak yavaş hareketi ortaya çıkmıştır. Hareket, modern dünyadaki hızlı yaşama alternatif olarak, daha iyi ve kaliteli bir yaşamı öneren bir felsefeyi, diğer bir deyişle kültürel bir devrimi ifade eder (Honore, 2008).

Sakin şehir kavramının temelini yavaş hareketi oluşturmaktadır. Yavaş hareketi, bir mücadele alanı olarak 1986'da Roma'da, resmi olarak 1989'da Paris'te geleneklerin ve yerel yemek kültürünün küresel işletmeler karşısında yok olması tehdidine karşı ortaya çıkan, tabandan doğan yavaş gıda hareketi ile başlatılmaktadır ("Slow Food International", t.y.). Gıdadan modaya, hatta seyahat anlayışına kadar uzanan yavaş hareketi yerel ve geleneksel değerleri koruyup, sürdürülebilirliği desteklerken, büyük ölçekli ve küresel nitelikteki işletmelere de karşı durur (Mayer ve Knox, 2009, s. 25).

"Cittaslow" (sakin şehir) belirli ölçütlere uygun olan ilçelerin üye olabildiği uluslararası bir belediyeler birliğidir. Sakin Şehir Birliği, İtalya' da 1999 yılında doğmuştur Yaşam kalitesini yükseltmek amacıyla başlayan hareketin lideri Greve in Chianti'nin (İtalya Toscana) eski Belediye Başkanı Paolo Saturnini'dir ("Slow", t.y.). Sakin şehirler küreselleşmenin de etkisiyle içinde 
bulundukları coğrafyanın ruhunu, kimliğini taşımayan karaktersiz kentlere bir alternatif olarak ortaya çıkmıştır (Semmens ve Freeman, 2012).

II. Dünya savaşından sonra ülkelerin benimsediği hızlı sanayileşme stratejilerinin var olan eşitsizlikleri derinleştirmesi, sömürüyü arttırması ve çevreye zarar vermesi neticesinde 1987 yılında Birleşmiş Milletler'in Brundtland Raporu'nda sürdürülebilir kalkınma kavramının tarih sahnesine çıkmasıyla Gündem 21 uyarınca yerel yönetimlere de görev düşmüştü. Sürdürülebilir kalkınma ilkeleri doğrultusunda gelişen, yerel yönetimlerin bu uygulamalarda başı çektiği sakin şehirlerin tüm dünyada tanınırlığının artması popülerleşmeyi de beraberinde getirmiştir.

\section{Sakin Şehir Hareketinin Temelleri ve Niteliği}

Kolektif tüketimin gerçekleştiği mekânlar olarak kentlerin ekonomik ve ideolojik düzlemde belirleyici yerler olduğu tartışılırken (Castells, 1983) küreselleşmenin yükselişi ile küçük veya büyük fark etmeksizin çoğu kentte aynılaşma süreci yaşanmıştır (Harvey, 2003; Radstrom, 2011). Sakin şehir yerel aktörlerin kentsel alanlara yönelik sağlık, yerel değerler, kültür ve çevre alanlarındaki ihtiyaçları sonucu ortaya çıkmış olup, bu talepler alandaki bazı sosyal bilimcilerin "yeni sosyal harekeler" (Cohen ve Arato, 1992; Çayır, 1999; Habermas, 1981; Offe, 1985; Tilly, 1985; Touraine, 1992) bazılarınınsa "çağdaş sosyal kent hareketleri" (Castells, 2002; Leontideu, 2006; Mayer ve Knox, 2006, McCann 2008, Pink, 2009), "dolayll aktivizm (indirect activism)" (Pink, 2009) olarak ifade ettiği kavramsal çerçevede anlam kazanmaktadır.

Paradigma, "yeni sosyal hareketler" olarak kavramsallaştırılırken, hareketin niteliği 20.yy. ortası ile sonlarında ortaya çkan ikinci dalga sosyal hareketlere denk düşer. Bu dönem kadınlara, azınlıklara, çevreye yönelik hakların yeni yasal düzenlemelerle korunması sağlanırken, ulusal ve uluslararası kazanımlar mümkün olmuştur (Atvur, 2014). Castells, çevre hareketinin gelişimini ve yerel hareket gereksinimini, "aktivizm" ve "ekolojik düşünce" ile bağlantılı açıklar. Castells (2002-2000)'e göre kent alanları giderek artan oranda çevrecilik tarafından ortaya çıkartılan küresel konular ve yaşam kalitesi (yerel deneyim) arasında birleşim noktası haline gelmeye başlamıştır.

\section{Dünyada ve Türkiye'de Sakin Şehir Uygulamalar}

Sakin şehir hareketi 2021 yılı itibarıyla dünya çapında 30 farklı ülkede, 278 üye kentte uygulanmaktadır ("Cittaslow International",t.y.). Beatley (2005, s. 335)'e göre "sakin şehir ağındaki üye ilçelerin her biri farklı özelliklerle ön plana çıksalar da, onları buluşturan ortak nokta özgün özelliklerini koruma arzusu"dur. Hareket, uluslararası niteliğe bürünmesi ile tüzüklerde 6 temel 
alan (çevre, alt-yapı, kentsel yaşam, yerel ürünler, misafirperverlik ve eğitim) aynı kalmak üzere göstergelerin sayısı ve türleri ülkeler bağlamında uyarlanarak bazı değişiklikler gösterecek şekilde düzenlenebilmektedir.

İtalya'da ilk ortaya çıkan hareketin Avrupa'da yoğunlaşması, yerel unsurların hemen hemen ortadan kalktığı, küreselleşmeyle birlikte gelen tek tipleşmenin hüküm sürdüğü bu topraklarda duyulan ihtiyacı ortaya koymaktadır (Özür Karakaş, 2016). Dünyada 50'den fazla sakin şehirle başı çeken İtalya örneğinde, uzun bir sahile sahip olan Cinque Terre üzüm bağları ve şarapları; Levanto, Castelnovo Monti ve San Miniato kentsel tasarım ve kent merkezi, Orvieto ise sürdürülebilir ulaşım gibi unsurlarla tanınmaktadır (Mayer ve Knox, 2009).

Dünya kapsamında İtalya, Almanya ve Avusturya örnekleri üzerinden uygulamalara örnek olarak yer verilecektir. İtalyan ilçelerde atık yönetimi, ışık kirliliğinin azaltılması (Levanto, vb.) gibi çevresel boyutlara ağırlık verilmesi ve turizm (Cinque Terre, Levanto, Cinque Terre, vb.) yoluyla yerel ekonomik kalkınmanın sağlanması gibi unsurlar vurgulanırken; Alman ilçelerinde yerel ürünlerin üretimi ve pazarlanması, yemek ve beslenme eğitimleri ve alternatif enerji sistemlerinin uygulanması ön plana çıkmaktadır.

Almanya örneğinde, Hersbruck bir ortaçağ mimarisi örneği sergilerken, Nuremberg'in art alanı olması nedeniyle hafta sonu ziyaretçileri yoğundur. Mera alanları ve bahçelerin korunması için çevreci grupların çiftçiler, yerel yöneticiler ve küçük işletmecilerle ortak çalışmalar yaptıkları bilinmektedir. Waldkirch örneği ise çiftçi pazarlarına ilçe merkezinde yer verme, yerel alternatif enerji kaynakların kullanma ve dezavantajlı sosyo-ekonomik grupların entegrasyonu (Topluluk Geliştirme Merkezi- Red House) çabalarıyla tanınmaktadır (Mayer ve Knox, 2009). Avusturya örneğinde, uygulamalarda elektrikli bisikletlerin kullanımının teşvik edilmesi, bisiklet yolları ve ücretsiz otobüs gibi ulaşım olanaklarının geliştirilmesi ön plana çıkmaktadır (Arıkan, Dündar ve Edlinger, 2015).

Türkiye ise dünyadaki sakin şehir ailesine ilk olarak Seferihisar'ın 52 ölçüte göre değerlendirilerek, \%73 düzeyinde uygunluk sağlaması sonucu 2009' da katılmıştır (Şahinkaya, 2010). İzmir'e 45 km mesafede bulunan, bozulmamış doğası, $60 \mathrm{~km}$ 'lik sahil şeridi, bereketli toprakları ve kültürel mirasıyla ön plana çıkan Seferihisar örneğinde hareket üretici birliklerinin (mandalina, zeytin, enginar ve üzüm) ve kooperatiflerinin (SS. Hıdırlık Tarımsal Kalkınma Kooperatifi) kurulması, yerel ürünlerinin pazarlanması (Seferipazar web sitesi), organik ve iyi tarım uygulamaları ve turiz- 
min canlandırılması ile gelişim göstermiştir. Yerel üretimin teşvik edilmesinin yanı sıra üretici pazarları ile ürünün kaynağında, yerelde tüketici ile buluşturulması sağlanmakta; sağlıklaştırma projeleri ile kentsel mekân yeniden düzenlenmekte, etkinlikler ve eğitimlerle sakin şehir ruhu dinamik tutulmaktadır.

Türkiye'nin Seferihisar ile birlikte başlayan yolculuğunda sakin şehir sayısı 18'e yükselmiştir ("Cittaslow Türkiye", t.y.). Vize (Kırklareli) yüzyıllardır devam eden gelenekleri, mutfak kültürü ile; Ege denizinde bulunan dünyanın ilk sakin şehir adası Gökçeada (Çanakkale), organik tarımı, Rum Ortodokslara ev sahipliği yapması, turizmi ve kültürel etkinlikleriyle; Akyaka (Muğla) geleneksel mimarinin tüm kente uygulanması, ekolojik yaşamı ve sahilleriyle; Yenipazar (Aydın) yerel mutfağı, gelenekleri ve parklarıyla; Taraklı (Sakarya) özgün mimarisi ve kaplıca turizmi ile; Yalvaç (Isparta) özgün hamur işleri yapan fırınları, özgün örf ve adetleri, geleneksel el işçiliği (tahta, tarak, kaşı vb.) ve yöresel Uhud tatlısı ile ön plana çıkmaktadır (Çıttak, 2016; Yüksel Özmen, Birsen, ve Birsen, 2016).

Böylece ölçütlerin uygulanmasında ilçeden ilçeye ve ülkeden ülkeye farklılıklar görülebilmektedir. Kentsel planlama, yaşam kalitesi, yaşamın hızı, ekonomik etkinlikler ve sürdürülebilirlik konularında incelenen örnekler bağlamında önemli düzenlemeler bulunmaktadır. Bu uygulamalarla bir taraftan yerel değerler korunurken, diğer taraftan ilçelerin küresel ağ sistemi içindeki yeri korunarak iletişimin sürekliliği sağlanır (Miele, 2008).

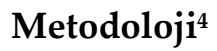

Araştırma kapsamında karma yöntem benimsenerek nitel ve nicel teknikler bir arada kullanılmıştır. Anlama ve yorumlamaya dayalı betimleyici araştırma nitel yöntemle yürütülürken (Kümbetoğlu, 2005); açılamaya dayalı nicel yöntemin de birlikte kullanılmasının (Keat ve Urry, 1994) çalışmayı daha da güçlendirdiği düşünülmektedir. Araştırmanın aktörleri sakin şehir uygulamalarında rol alan kuruluşları ve bu hizmetlerden yararlanan kişileri kapsamaktadır. Araştırmanın nitel aşaması kapsamında yargısal örneklem tekniğine göre belirlenen Tablo 1' de belirtilen aktörlerle derinlemesine görüşme yapılarak, nitel veri analizi esasına göre ve-

\footnotetext{
${ }^{4}$ Araştırma kapsamında Etik Kurul Raporu 19.10.2016 tarihinde İstanbul Okan Üniversitesi'nden alınmıştır.
} 
rilerin analizi yapılmıştır. Görüşmecilerin kimliklerinin gizliliğini korumak adına uzman katılımcılar $\mathrm{K}$; muhtarlar ise $\mathrm{M}$ harfi ile kodlanarak numaralandırılmıştır (Bkz. Tablo 1).

Tablo 1. Veri Toplanan Kişi/Kuruluşlar ve Veri Toplama Teknikleri (Kaynak: Seferihisar Saha Çalışması, 2016-2017)

\begin{tabular}{|c|c|c|}
\hline Kişi/Kurum Adı & Yer Bilgisi & Veri Toplama Teknikleri \\
\hline Yerel Halk & Seferihisar Mahalleleri & $\begin{array}{l}\text { Anket, Kısmi Katılımlı } \\
\text { Gözlem }\end{array}$ \\
\hline Muhtarlar & Seferihisar Mahalleleri & Derinlemesine Mülakat \\
\hline $\begin{array}{l}\text { Seferihisar Belediye } \\
\text { Başkanlı̆̆ı }\end{array}$ & Seferihisar Belediyesi & Derinlemesine Mülakat \\
\hline $\begin{array}{l}\text { Sakin Şehir Türkiye } \\
\text { Uzmanı }\end{array}$ & Seferihisar Belediyesi & Derinlemesine Mülakat \\
\hline $\begin{array}{l}\text { Yavaş Yaşamı } \\
\text { Destekleme Derneği }\end{array}$ & $\begin{array}{l}\text { Yavaş Yaşamı Destekleme } \\
\text { Derneği (İzmir Merkez) }\end{array}$ & Derinlemesine Mülakat \\
\hline Kadınlar ve Üreticiler & Sığacık Pazarı, Üretici Pazarı & $\begin{array}{l}\text { Serbest Görüşmeler, } \\
\text { Kısmi Katılımlı Gözlem }\end{array}$ \\
\hline
\end{tabular}

Araşırmanınnicel aşamasının evrenini Seferihisar ilçesi, ömeklemini ise ilçenin mahallelerinden(Sığack, Tepecik, Turabiye, UlamışveÇolakỉbrahimbey) "oranlı tabakahl ömekleme" yoluyla seçilen toplam 332 kişi (187 erkek 145 kadın) oluşturmaktadır. Anket formunun geliştirilmesinde alandaki çalışmalar yönlendirici olmuştur (bkz. Çakıa, Yenipınar ve Benli, 2014; Ekincek ve Aksöz, 2016; Yüksel Özmen, vd., 2017;). Yüzyüzeuygulanan anket tekniği yoluyla toplanan veriler SPSS 21 (Statistical Package For Social Sciences) aracllğı̆la işlenerek; tanımlayıa istatistik doğrultusunda hazırlanan tablolar ile sunulmuştur.

Anket formunda bulunan ölçek tipi sorularn güvenilirliği Cronbach's Alpha güvenirlilik katsayıs kullanılarak hesaplanmışır. Bu araştırmada likert tipi ifadelerin yer aldığı bölümde genel Crobach alfa kat sayıs 0,879 olup, kat sayının 0,80-1,00 aralığında olması anketteki ölçek sorularının güvenilirliğinin yükssek olduğunu göstermektedir (Nakip, 2013).

\section{Bulgular ve Tartışma}

\section{Hareketin İçe Örneğinde Olumlu Etkileri: Fursatlar Turizmin Gelişmesi}


Sakin şehir uygulamasının faydaları katilımclar tarafindan önem sırasına göre olarak "turizmin gelişmesi" (\%27), "iş olanaklanı sağlaması" (\%18) ve "yaşam düzeyinin yükselmesi" (\%18) olarak değerlendirilmiştir (Bkz. Tablo2). Sakin şehrin amaçları ise katilımcların \%26'sına göre "turizmi geliştirmek", \%19'una göre "yerel kalkınma", \%18'ine göre "yaşam kalitesi" ve \%18'ine göre "tarihi ve kültürel dokuyu korumak"tır (Bkz. Şekil 1). Bu noktada asıl amaç olması gereken sakin şehir felsefesinin gerektirdiği çevreyi koruma sıralamada ilk üçe giremezken, turizm amaçlar ve faydalar bakımından ilk sırada, "yaşam kalitesi” ise 3. sırayı alabilmiştir. Unvan sonrasında yerel halkın turizm konusunda olumlu görüşe sahip olduğunu (Andarabi, 2012; Çakıc vd., 2014), yaşam doyumunun arttğıı (Çakıa vd., 2014) ortaya koyan çalışmalar bu araştırmanın sonucu ile paralellik göstermektedir.

Tablo 2. Katılımcılara göre Faydalar

\begin{tabular}{lll}
\hline & Sayı & $\%$ \\
\hline Turizmin gelişmesi & 79 & 27,3 \\
İş olanakları sağlaması & 53 & 18,3 \\
Yaşam düzeyinin yük- & 52 & 18,0 \\
$\begin{array}{l}\text { selmesi } \\
\text { Yeni geçim kaynakları }\end{array}$ & 50 & 17,4 \\
Kültür sanat faaliyet- & 42 & 14,4 \\
leri & & \\
Diğer & 13 & 4,5 \\
\hline Toplam & $\mathbf{2 8 9}$ & $\mathbf{1 0 0 , 0}$ \\
\hline & &
\end{tabular}

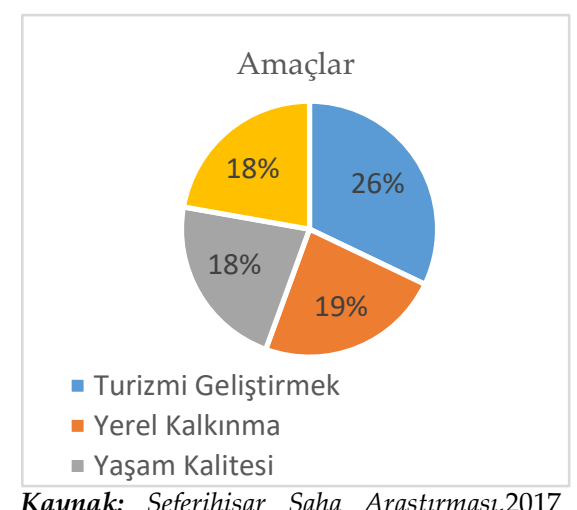

Kaynak: Seferihisar Saha Araştırması,2017

Şekil 1. Katılımcılara göre Amaçlar

Seferihisar örneğine benzer olarak "Cittaslow" unvanı dünyada çeşitli örnekler (İngiltere, İspanya, İtalya ve Almanya) üzerinden de görülebileceği gibi turizmin gelişmesi ve unvanın bir pazar stratejisi olmasıyla sonuçlanmıştır (Mayer ve Knox, 2009; Servon ve Pink, 2015). İspanya örneğinde, önceden ağırlıklı olarak balıkçılık (Lekeitio) veya tarıma dayalı (Pals ve Rubielos de Mora) yerel ekonomiler tarımın endüstrileşmesi ve balıkçılıkla ilgili kısıtlamalar sonucunda kökten değişmiştir. Böylece birçoğu (Pals, Begur, Lekeitio, Mungia, Rubielos de Mora ve Bigatro) işletme ve turistleri etkilemek için pazarlama sürecine dâhil olmuşlardır. Ancak bu sakin şehirlerde turizmin ekonomik boyutun ötesine geçerek mekan ve kültür açısından olumlu bir fenomen olarak görüldüğü savunulmaktadır (Blanco, 2011; akt. Servon ve Pink, 
2015). Radstrom'a (2011) göre ise turizm hiçbir zaman öncelik değildir. Örneğin Perşembe'de halkın turizmin önemli unsurlarından biri olan ev pansiyonculuğu konusunda tutucu davrandığı ortaya koyulmaktadır (Çıtak, 2016).

İlçede turizmin gelişmesinin en önemli nedenlerinden birisi olarak “Tanıtım" olarak değerlendirilmektedir (Çerçi, 2013; Grzelak-Kostulska, Hołowiecka, ve Kwiatkowski, 2011; Öztürk, 2012; Servon ve Pink, 2015). Unvan şehirlerin ekonomik olarak kalkınmasını sağlarken şehri turizm için çekici bir konum haline getirmektedir. Sakin şehir hareketinin markalaşma üzerinde etkili olduğu görüşü ile paralellik gösteren çalışmalar bulunmaktadır (Çerçi, 2013; Grzelak-Kostulska, vd., 2011; Servon ve Pink, 2015).

İlçenin sakin şehir unvanı alması sonucunda tanınırlığının artmasını bir katılımcı şöyle ifade etmektedir:

“...Seferihisar'ı İzmir bile bilmiyordu. Dizilerle tanındık. Başkanın da etkisi çok büyük. Son 5 yildır iyi tanındı. Şimdi burada tezgâh açanlar ayda en az 1.000 TL. para kazanıyor" (Sığacık Mahallesi, Kadın, 50 yaş, 8 Nisan 2017).

Mayer ve Knox (2006) çalışmalarında sakin şehir markasının yerel halkın yaşam kalitesini arttırdığını ve bölgenin ekonomik gelişmesine katkı sunduğunu belirtmişlerdir. İlçe örneğinde, yerel halk, kuruluş temsilcileri ve muhtarlar ilçenin tanınırlığının arttığı konusundaki ortak görüşü paylaşmaktadır.

\section{Yeni Isş Olanaklan ve Kalkınma Politikalan}

İlçe, unvanı elde ettiği 2009 yılından 2020 yılına kadar gelirlerini yaklaşık 7 katına çıkartmıştır ("Faaliyet Raporları". t.y.). Veriler, yıllar içinde üyeliğin ilçeye sağladığı ekonomik faydayı ortaya koymaktadır. İlçenin unvanı almasının en çok kime fayda sağlayabileceği ile ilgili soruya katılımcıların \%25'i "turizmle uğraşanlar", \%23'ü "kadınlar" ve \%14'ü "esnaf" yanıtını vermiştir (Bkz. Şekil 2). Böylece ilçedeki çeşitli meslek gruplarının ve her kesimden halkın fayda sağlayabileceği görüşü hâkimdir.

Kalkınma politikaları ile ilgili olumlu görüş bildirilen başlıklar ve

yüzdelikleri oransal olarak ekonominin canlanması (\%73), gelir artışı (\%65), kalkınma politikaları (\%50), tarımın gelişmesi (\%42) ve gençler için istihdam (\%8) olarak sıralanabilir (Bkz. Şekil 3). "Yerel ekonominin canlanması" ve "gelir artışı" en üst sırada yer alırken; en düşük katılım "istihdam" da görülmektedir. Çakıcı vd. (2014)'nin çalışmasında hareket, önem s1rasıyla kültürel, ekonomik, refah ve doğal çevre konularında etki yapmıştır. 


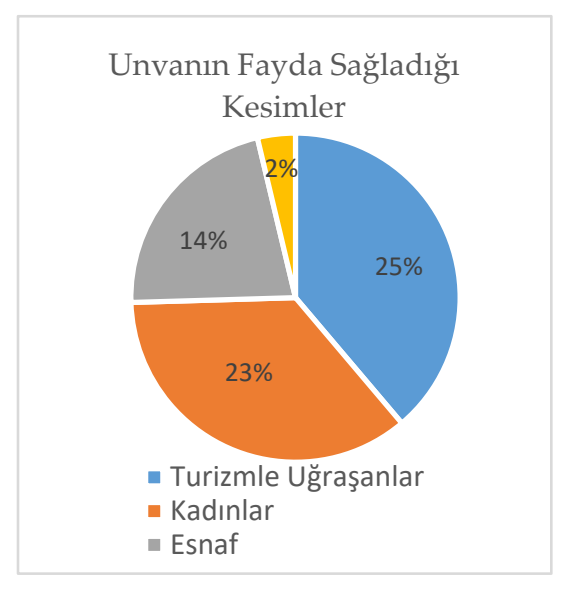

(Kaynak: Seferihisar Saha Araştırması, 2017)

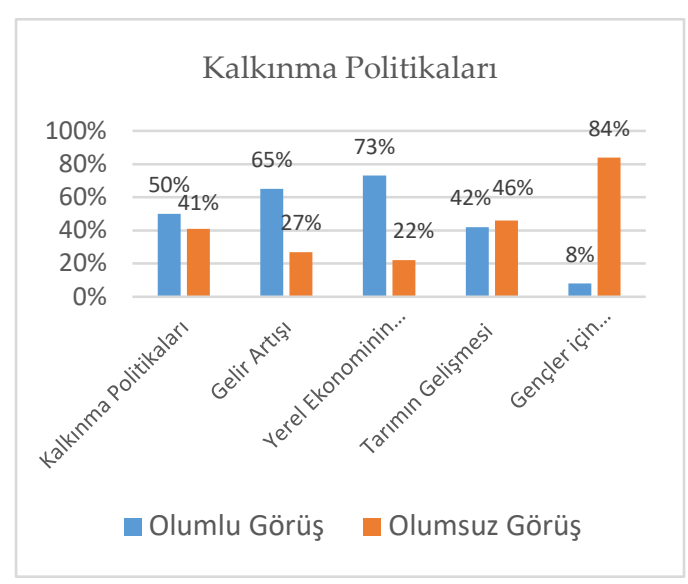

(Kaynak: Seferihisar Saha Araştırması, 2017)

Şekil 2. Unvanın Fayda Sağladığı Kesimler

Ekonominin canlanması ve gelir artışında en önemli faktör ilçede ekonomik kaynak olarak turizmin başı çekmesidir. 2014 yılında Sığacık Kaleiçi Sağlıklaştırma projesinin tamamlanmasıyla birlikte turizm gelişmiştir. Kalkınma kapsamında ilçede üretici birlikleri Belediye tarafından desteklenmekte, ürünlerin markalaştırılması sağlanmaktadır. Hareketin fayda sağladığı aktörler bakımından kadınların ikinci sırada yer alması (bkz. Şekil 2) hareketin kadınları güçlendirici yönünü ortaya koymaktadır.

Kadın istihdamının arttığı ilçede, uygulamalar konusunda en büyük toplumsal desteği veren kesimlerin başında kadınlar gelmektedir. K1'in ifadesiyle "Seferihisar'da lokomotif en başından beri kadınlar olmuştur" (Seferihisar Belediyesi Temsilcisi, 7 Nisan 2017). İlçede üretici pazarı, gece pazarı, Seferibakkal ve Seferipazar gibi oluşumlarla yerel ürünlerin satışı sağlanırken; atalık tohumla üretilen gıdalar veya iyi tarım uygulamalarıyla sağlıklı ürünlerin üretimi özendirilmektedir.

Taraklı örneğinde, yerel ürünlerin satışı için marketlerin açılması, pansiyon ve konaklama evlerinin açılması, geleneksel ahşap işçiliği gibi geleneksel mesleklerin canlandırılması, turizm ve tarım anlamında önemli gelişmeler yaşandığı belirtilmektedir (Çiçek, Ulu ve Uslay, 2019). İlçede unvanla birlikte çevre bilincinin, yerel ürünlerin pazarlanmasının ve turist oranının arttığı tartışılmaktadır (Değirmenci ve Sarıbıyık, 2015). 


\section{Hareketin İlçe Örneğinde Olumsuz Etkileri ve Sürdürülebilirliğin Önündeki Engeller}

\section{İlçenin Dayanılmaz Çekiciliği ve Nüfus Artışı}

İlçenin 2008-2019 yılları arasında nüfusu yaklaşık \%65 oranında (17.581 kişi) artmıştır. Bölgeye göçün ilçenin sakin şehir unvanı almasından sonra hızlandığı muhtar mülakatlarında da ifade edilmiştir. Fondazione Censis (2011) tarafından 61 sakin şehir üzerine yapılan çalışmada, sakin şehirlerin gelişme eğiliminde olup, son 10 yıla oranla nüfuslarının \%12 oranında artışta olduğu ortaya konulmuştur (akt. Servon ve Pink, 2015). Diğer taraftan, İspanya örneği (Pals, Begur, Lekeitio, Mungia, Rubielos de Mora ve Bigatro), ortalama 6.408 kişilik nüfus ile tipik bir sakin şehre göre daha az nüfusa sahiptir (Servon ve Pink, 2015).

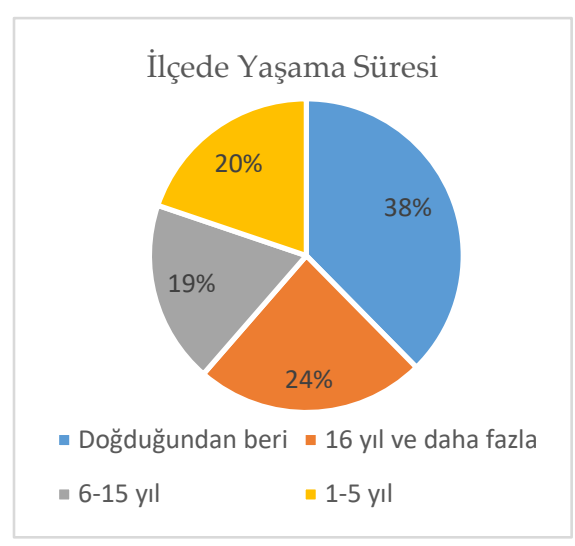

(Kaynak: Seferihisar Saha Araştırması, 2017)

Şekil 4. İcçede Yaşama Süresi Dağılımı

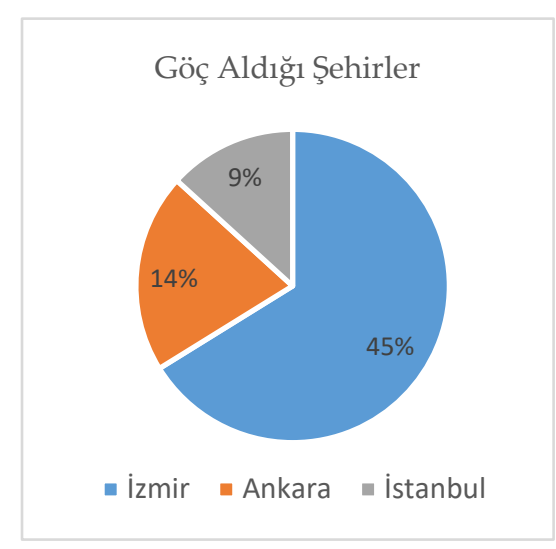

(Kaynak: Seferihisar Saha Araştırması, 201)

Şekil 5. Son 5 Yılda Göç Alınan Şehirler

Şekil 4'te de görüldüŭü gibi ilçede yaşama süresi "1-5 yll” olan katilımcların (\%20) geldikleri şehirler üç büyük şehir olmak üzere \%45 İzmir, \%14 Ankara ve \%9 ileİstanbul'dur (Bkz. Şekil 5). Kathlımcların önemli bir kısmı yaşam kalitelerini arttırmak, daha sakin bir yerde, daha sağlıklı yaşamak amacıyla büyük şehirlerden ilçeye yerleşmişlerdir. Bu konudaki toplumdaki ihtiyaa K1 (Seferihisar Belediyesi Temsilcisi, 7 Nisan 2017) şöyle ifade etmiştir:

"Kentlerdeki gerginliği, telaşı, trafiğibir kenaraburakp bir dağ köyüne yerleşmek, bir balıķı kasabasında ömrünün kalanmm geçirmek gibi hayaller var akullarm bir köşesinde."

Yerleşik nüfusun yanı sıra ilçeye tatilleri değerlendirmek için turistik amaçı gelen ziyaretçiler de bulunaktadır. Özellikle yaz aylarında nüfusun 200.000'e yaklaşması ilçede sakin şehir ölçütlerinden birisi olan, nüfus ölçütlerinin 2017 yllından itibaren 
aşılmış olduğunu ortaya koymaktadır. Özellikle bahar ve yaz ayları pazar günleri Sığack Kaleiçi'de kurulan pazar alanında önemli düzeydebir yoğunluk yaşanmaktadır. Katilımclar bu dönemde insan yoğunluğunun "yere iğne düşmeyecek" bir boyuta taşındığını belirtirken ilçenin "sakinlikten çıktığı" nı vurgulamışlardır.

İlçenin sakin şehir olmasının ne gibi sorunlara yol açabileceği ile ilgili soruda katullmaların \%52'si "nüfus artşı", \%19'u "inşaat artş̧" ve \%10'u "çarpık yapılaşma" yanitı vermiştir. Elde edilen bu bulgular doğrultusunda ilçenin çekici faktörleri sonucu özellikle büyük kentlerden göç alması sonucunda ilçede kentsel alanlarda sıklıkla gözlemlenen problemlerin ortaya çıktı̆ı söylenebilir. Böylece kentliler, kentleilgili sorunları ilçeye taşımıştır (bkz. Tablo 3).

Tablo 3. Unvanın Yol Açabileceği Sorunlar

\begin{tabular}{lcc}
\hline & Sayı & $\%$ \\
\hline Nüfus artşı & 167 & 51,5 \\
İşsaat artşı & 62 & 19,1 \\
Çarpık yapılaşma & 31 & 9,6 \\
Tarım alanında azalma & 27 & 8,3 \\
Çevre kirliliğinde artş & 9 & 4,9 \\
Gelir eşitsizliğinde artş̧ & 16 & 3,7 \\
Diğer & 12 & 2,8 \\
Toplam & $\mathbf{3 2 4}$ & $\mathbf{1 0 0}$ \\
\hline
\end{tabular}

Sakin Şehir Birliğine üyelik sakin şehirlere doğrudan bir katkı sağlamazken, tanınırlı̆ı̆n artışı ilçede turizmin gelişmesini hızlandırır. Özellikle Seferihisar gibi coğrafi avantajlara sahip olan yerleşimlerin ekonomisi turizm gelirlerine bağımldır. Diğer taraftan, ilçenin dokusuna uygun olmayan ve iyi planlanmamış bir turizm anlayışı ise sürdürülebilirliğin önünde bir engel teşkil etmektedir.

\section{Kent, Çevre ve Yetki Alanı Sorunları}

Sakin şehir hareketine yöneltilen en önemli eleştirilerden birisi hareketin organizasyon yapısı gereği "sosyal kent hareketleri" olarak işlev göremeyeceği tartşmasıdır (Pink, 2009, s. 457). Sakin Şehir Birliğine üye olan ilçelerin Belediye ve kent konseyleri ile doğrudan birlikte çalıştı̆ı dikkate alındığında Sakin Şehir Birliğinin yerel yönetim içinde gömülü olduğundan söz edilebilir. Böylece, bu girişimin doğuştan bir alternatif geliştirme konusunda başarısızlığı tartışılmaktadır (Kavoulakos, 2006; Pink, 2009).

Tesis ya da yatak sayısı gibi herhangi bir kapasite sınırı bulunmayan ilçenin 50 bin olan nüfus sınırının yakın gelecekte aşılacağı tahmin edilmektedir. Bazı katılımaların bu konudaki ifadeleri şöyledir: 
"Sakin şehir amacindan saptt. Rahatlamış trafik ve sessiz bir ortam yok. Ambulans bile kilitleniyor burada trafikte (Hidirlık Mah., Kadm, 30 yaş, 10 Nisan 2017)."

"Çocuklar rahatça oynayamiyor. Yeşil yok. Her yer bina oldu, beton oldu. Bizim çocukluğumuzda bu kadar bina yoktu, rahat ve yeşildi" (Camikebir Mah., Kadm, 42 Yaş, 11 Nisan 2017).

Kentler sermayenin önemli bir bileşeni olarak işlev görürken, en önemli sektörlerden birisini de inşaat sektörü oluşturmaktadır. Yapılaşmanın yanı sıra, çiftçiye verilen desteklerin azlığı ve mandalinanın artk para getirmemesi nedeniyle tarımsal üretimin azaldığı sıkça ifade edilmiştir. Sakin şehirlerdeki üretim anlayışı ekonomik gelişimi destekleyen veçevreyle de uyumlu bir kalkınma anlayışını benimserken (S1rım, 2012), Seferihisar örneğinde kent ve çevre sorunları bulunmaktadır.

\section{Toplumsal Kabul}

Unvanın ilçeye katkı yapıp yapmadı̆̆ı konusunda mahalleler arası görüş farkllıkları bulunmaktadır. "Toplumsal kabul”e ilişkin verilere göre, sakin şehir unvanı ve uygulamaları ilçede katılımciların yarısından fazlası (\%58), tarafindan toplumsal olarak kabul görmekteyken, dörtte biri (\%27) tarafindan benimsenmeyip kabul görmediği söylenebilir (Bkz. Tablo 4). A1 ifadesi \%79 oranında kabul görürken, A2 ve A3 ifadeleri de sirasına göre $\% 68$ ve $\% 66$ oranında kabul gören ortalamanın üzerindeki; A4 \%44, A5 \%42 ve A6 \%51 oranında kabul gören, ortalamanın altında kalan değerlerdir (Bkz. Tablo 4).

Tablo 4. Sakin Şehir Konusunda Toplumsal Kabul

\begin{tabular}{|c|c|c|c|c|c|}
\hline 参莺 & 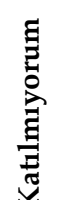 & 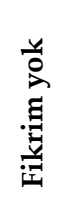 & 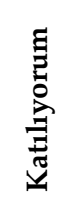 & 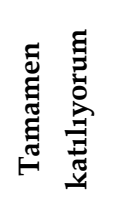 & 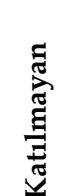 \\
\hline
\end{tabular}

\begin{tabular}{lrrrrrrrrrrrrr}
\hline İfade & Say1 & $\%$ & Say1 & $\%$ & \multicolumn{1}{l}{ Say1 } & $\%$ & Say1 & $\%$ & Say1 & $\%$ & Toplam & $\%$ & $\%$ \\
\hline A1 & 30 & 9,1 & 18 & 5,5 & 23 & 6,97 & 124 & 37,6 & 135 & 40,9 & 330 & 14,6 & 78,5 \\
A2 & 34 & 10,2 & 48 & 14,5 & 23 & 6,93 & 78 & 23,5 & 149 & 44,9 & 332 & 24,7 & 68,4 \\
A3 & 37 & 11,1 & 40 & 12,1 & 35 & 10,61 & 136 & 41,2 & 82 & 24,9 & 330 & 23,3 & 66,1 \\
A4 & 64 & 19,3 & 26 & 7,9 & 96 & 29 & 76 & 23,0 & 69 & 20,9 & 331 & 27,1 & 43,8 \\
A5 & 60 & 18,1 & 74 & 22,3 & 60 & 18,07 & 85 & 25,6 & 53 & 16,0 & 332 & 40,4 & 41,6 \\
A6 & 63 & 19 & 37 & 11,2 & 61 & 18,43 & 86 & 26,0 & 84 & 25,4 & 331 & 30,2 & 51,4 \\
\hline & & & & & & & & & & Ottalama & 26,6 & 58,2 \\
\hline
\end{tabular}




\section{${ }^{5}$ İfadeler}

İlçe, kültürel değerlerini koruyan özgün bir kentsel mimariye sahip olması bakımından Sığacık Mahallesi Kaleiçi Bölgesi ile ön plana çıkmaktadır. Denize yakın konumu, marinası, üretici pazarı, pansiyon ve kafeleriyle Sığacık farklılaşmaktadır. Sığacık halkının pazarlarda kendi ürünlerini satarak gelir elde edebileceği gibi mahallede bulunan konaklarını turizme açarak da gelir düzeyini artırma olanakları vardır. Mahalleler arası gelir dağılımındaki farklılıklar ve siyasi görüş farklılıkları, toplumsal kabul konusunda yöre halkının ikiye ayrılması ile sonuçlanmıştır. M1 (Çolak İbrahimbey Mahallesi Muhtarlığı, 8 Nisan 2017), tesislerin genellikle tam pansiyon olduğu ve turistlerin S1ğacık dışında başka mahallelere gitmediği konusundaki görüşlerini ifade ederek şunları eklemiştir:

"Reklam ve tanıtım daha iyi oldu. Ama esas Sı̆̆acık'a ağırlkk verildi. Burası üvey evlat gibi kaldı" (M3, Bengiler Mahallesi Muhtarlığı, 12 Nisan 2017).

"Sakin şehir amblemi aldık; ama hızlı şehir olduk. Barlar var. Burası çok kalabalık oldu" (M6, Turabiye Mahallesi Muhtarlı̆̆, 11 Nisan 2017).

Mahalleler arasındaki ekonomik farklılık artarken, diğer mahalleler ile S1ğacık arasında bir rekabet de başlamıştır. Bu durum halk arasında kavramın benimsenmesi ve toplumsal kabulünün önünde de en önemli engeli oluşturan faktörlerden birisidir. Üstündağlı, vd. (2015)'nin çalışmasında da belirtildiği gibi, ilçede sakin şehir felsefesinin tam olarak benimsenmesiyle ilgili eksiklikler olduğu, yerel halkın hareketi sürdürülebilirlik ilkesi yerine kişisel çkar temelli değerlendirdiği söylenebilir.

Toplumsal kabul boyutunun önemini K1 (Seferihisar Belediyesi Temsilcisi, 7 Nisan 2017) şöyle ifade etmiştir: “Tek silahımız tek gücümüz halkımız. Onların inanması, sahip çıması gerekiyor." Bu noktada toplumsal kabulün artması için de belediye, sivil toplum kuruluşları ile birlikte çalışmakta, ilçede etkinliklerini arttırmaları için destek sunmakta ve iş birliği yapmaktadır.

Pink (2009) sakin şehir hareketini kentsel sosyal hareket olmasının yanı sıra "yerel yönetişim modeli" olarak da ele alır. Yerel halkın karar mekanizması zincirinin bir halkası gibi hissetmesi bu modelin "katılımclık kur-

\footnotetext{
5 A1 İlçemizin sakin şehir unvanı alması ilçemize değer katmıştır.

A2 Sakin şehir unvanı bu şehir için gereklidir.

A3 Sakin şehir unvanı yalnız belediye başkanının kendi şahsına fayda sağlamaz.

A4 Gelir dağılımındaki farklılıklar "sakin şehir" kavramının benimsenmesini engellememiştir.

A5 Sakin şehir hareketinde halk ortak hedefler doğrultusunda birleşmiştir.

A6 Sakin şehir süreci siyasal sürtüşmelere neden olmamıştır.
} 
gusu"yla ilişkili olup, toplumsal kabul açısından da belirleyicidir. İlçede halkın \%47'si katılımcllı, \%55'i sosyal ve kültürel politikalar, \%50'si kalkınma politikaları, \%46'sı çevre politikaları konusunda olumlu görüşe sahiptir (Bkz. Şekil 6).

Veriler doğrultusunda sakin şehir uygulamalarında katılımcılığın halkın tabanına yayılması konusunda önemli atılımlar olduğu görülmektedir. Geliştirilen projelerle ilçede sosyal yaşamın geliştiği katılımcıların çoğu tarafından kabul edilmektedir. Çakıcı vd. (2014)'nin doğal çevreye, refah seviyesine, kültürel ve ekonomik etkisine göre yapılan faktör analizi çalışmasında benzer sonuçlar ortaya çıkmış, sakin şehir hareketinin önem sırasına göre kültürel yaşamı, ekonomik yaşamı, refahı ve doğal çevreyi etkilediği ortaya konulmuştur. Öztürk'ün (2012) çalışmasında da ilçede "gelir artışs" ve "belediye hizmetlerinin artışı" bulguları bu araştırma ile paralellik göstermektedir.

Şekil 6. Katılımcıların Politikalar Konusundaki Görüşleri

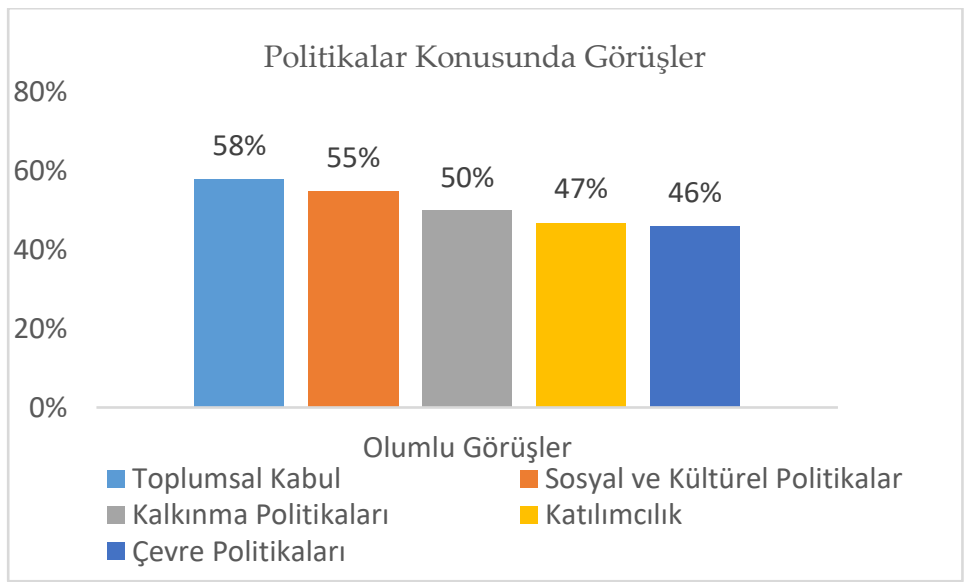

(Kaynak: Seferihisar Saha Araştırması, 2017)

Katılımcılar arasındaki görüş farklılıklarının kaynağını araştırmak amacıyla hane halkı ve katılımclar bazında olmak üzere mahallelerin eğitim durumuna göre dağılımları incelenmiştir. Katılımcıların eğitim durumlarını karşılaştırmak için gerçekleştirilen fark testleri sonuçları dikkate alındığında, eğitim düzeyi arttıkça sakin şehri destekleme eğilimlerinin arttğ söylenebilir (Bkz. Şekil 7). Eğitim durumuna göre yapılan Grzelak-Kostulska vd., (2011)'in araştrmasında da genç (30 yaş alt) ve eğitim düzeyi yüksek bireylerin hareketi desteklemesi eğilimi arasında doğru orantılı bir artış bulunmuştur. Sığack (\%75) en yüksek kabul oranına sahipken, Payamlı (\%39), Mersinalanı (\%33) \%50'nin altında kalan en düşük kabul oranına sahip mahallelerdir. 
Şekil 7. Eğitim Durumuna Göre Fark Testi Grafiği

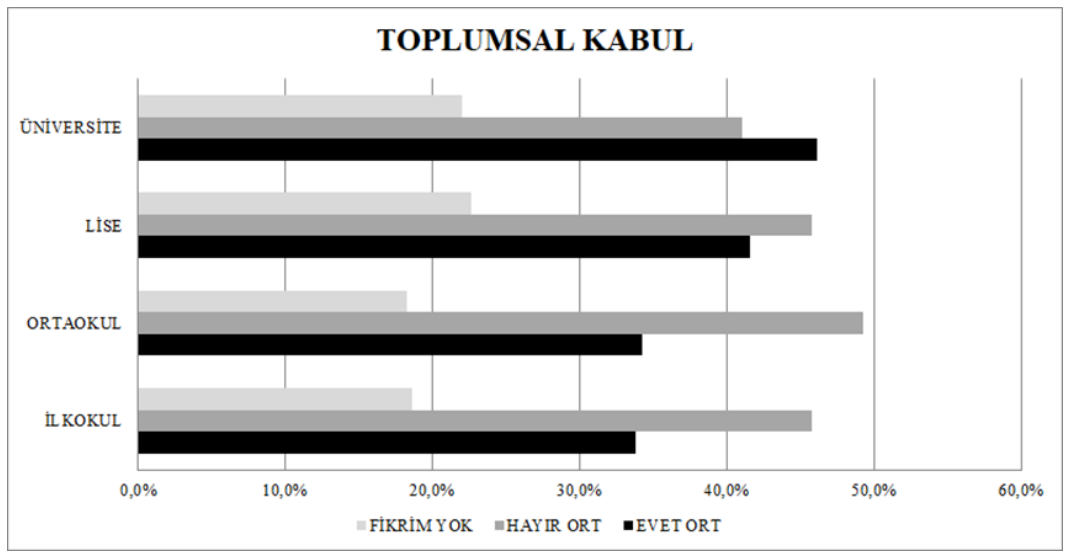

(Kaynak: Seferihisar Saha Araştırması, 2017)

Toplumsal katılımın sağlanmasında yerel yönetimin halkla işbirliği içinde olmasının önemi ve bu konudaki eksiklik Perşembe örneğinde de ortaya konulmaktadır (Şengür ve Atabeyoğlu, 2018). İngiltere (Pink, 2009) ve Yeni Zelanda örneklerinde (Semmens ve Freeman, 2012, s. 372) yerel topluluğun içinde yalnızca belirli bir azınlığın, belirli sınıfların sakin şehir projelerine dâhil olduğu bulgusu çalışma ile paralellik göstermektedir. Bu noktada en büyük zorluk, içeriğin sıradan vatandaşlar için teknik gelmesi ve halkın tamamına hitap etmemesi olarak görülmektedir.

\section{Sermaye Karşısında Sakin Şehirlerin Konumu ve Soylulaştırma}

1980 sonrası sermayenin kentleşmesi ile birlikte kent bir kar/rant kaynağı olarak (değişim değeri) görülmeye başlanmıştır (Şengül, 2001a, s. 34-38). Sakin şehir unvanı ile birlikte turist sayısının ve emlak fiyatlarının artması, aynı sürecin ilçe örneğinde de yaşandığını ortaya koymaktadır. İlçede toprakların değerlenmesi sonucu birçok kişinin toprağını, evini sattığı veya kiraya verdiği bilinmektedir. Doğanbey Mahallesi örneğinde yerel halkın bir kısmı evlerini satarak, bulundukları sitenin kapı görevliliğini üstlenmişlerdir.

Mahallelerdeki yerleşik halk ve yeni nüfusu bir araya getiren yeni mekânlar olarak çok katlı apartmanlar yeni sosyal gerçekliği inşa etmektedir. İlçe nüfus yapısı bakımından da değişikliğe uğrayarak, çeşitlenmiş (kentliler, göçmenler, işçiler, vb..), komşuluk ilişkileri değişmiştir. Birçok sakin şehirde yaygın olarak görüldüğü gibi Gökçeada, Halfeti ve Seferihisar ilçelerinde de günübirlik turizm de görülmektedir (Çıtak, 2016). Dizi filmlerinin de çekilmesiyle ilçeler (Halfeti, Seferihisar,..vb.) daha da meşhur olmaktadır. 
"Balıkçı köyü birden Hollywood köyü oldu. Komşuluk ilişkileri kalmadı, tarım alanlarını kesip biçerek imara açtılar. Çok fazla göç alıyor. Gittikçe Alaçatı'ya Bodrum'a benzemeye başladı" (Sığacık Mah., Erkek, 60 yaş, 9 Nisan 2017).

İlçede hareketin sürdürülebilirliği konusunda en önemli tehlikelerden birisi de kentin kendisinin meta olarak üretilir hale gelmesiyle (Lefebvre, 1991) birlikte sermaye karşısında sakin şehirlerin konumudur. Sakinlerin, kendi mahallelerinde oturmasının her geçen gün biraz zorlaştığı bu yeni durumda mekânda yabancılaşma süreci başlamaktadır (Erbaş ve Soydemir, 2011).

“...Ekonomik olarak getirisi var ama kendi duruşumuzu, köy evlerimizi arıyoruz, kendi içimizde kaybolduk" (Sı̆̆acık Mah., Erkek, 60 yaş, 9 Nisan 2017).

Yıllarca büyük ölçüde tarımla geçimini sağlayan halkın ilçe merkezinde traktörleri ile girebilecekleri bir alan kalmamış olması ve köylülerin dış görünüşleri ile önceden olduğundan daha fazla ilgilenir hale gelmeleri bu sürecin bir sonucu olarak görülebilir. Bell ve Jayne (2006, s. 10)'in ortaya koyduğu gibi sakin şehirlere ait, yerel özgünlük ve küçük şehir olma deneyimi gibi değerler, yerel sakinler tarafından değil de büyük şehirlerden gelen ziyaretçiler tarafından tüketilme riski taşır. Turizmin, unvanı alan ilçelerde vahşileşmesiyle (Akdoğan, 2017) yoğun turizm baskısı altında kalan bu yerleşimlerde yaşayan yerel halkın ilçeyi terk ederek evlerini otel ve benzeri işletmelere dönüştürmesi gibi durumlar ortaya çıkabilmektedir.

Sakin şehirlerin giderek daha çok tanınması ve popülerleşmesi sonucu daha varlıklı kesimin seçeceği ve dışarıdan gelenler için ikinci bir ev açmak isteyecekleri yerler haline geleceği öngörülmektedir. Bu durumda ev fiyatlarının yükselmesi, yoksullar ve gençlerin dışarı itilmesi ortaya çıkacak olan diğer etkilerdir (Knox, 2005, s. 8). Nilsson, Svärd, Widarsson ve Wirell (2011) ve Heitmann, Robinson, ve Povey (2011)'in ifade ettiği gibi sakin şehirlerde zengin tabakadan ziyaretçilerin bölgeye gelmesiyle gibi soylulaştırma riski ortaya çıkmaktadır. Nilsson vd. bu durumda konut ve arazi fiyatlarının sakin şehirlerde \%20-\%30 aralığında artabildiğini ve yeni konutların inşa edilmesine rağmen dairelerin yoğun bir hızda satıldığını ifade etmişlerdir. Tartışmalara paralel olarak 2015 yllı itibariyle Seferihisar gayrimenkul yönünden en çok değer arttıran ilçelerden birisi olmuştur. Neticede yerel halk yoksullaşırken, gelir farklılıkları artmıştır. Bir katılımcının bu konuda ifadesi şöyledir:

“5 senedir burası altın oldu. 100 liralk mal 2002'de şimdi 1 trilyon oldu. Yer fiyatları çok arttı, tanıdıklar azaldı. Burayı kiraya verip gidiyorlar" (Sı̆̆acık Mah., Erkek, 65 yaş, 9 Nisan 2017).

Fiyatların artışı yalnızca konut satışı ve kiralarındaki artışla sınırlı kalmamış, pazar fiyatlarına da yansımıştır. Konuyla ilgili ifadelerden birisi şöyledir: 
“İzmir' in en pahal ürünlerini burada biz yiyoruz. İzmir Üç Kuyular'da domates 2 TL iken, Camikebir'de 4 TL'den başlıyor" (Tepecik Mah. Erkek, 66 yaş, 10 Nisan 2017).

İlçede AVM, konut ve otel yapımının artması kapitalizmin içinde bulunduğu yeni aşama ile anlamlandırılabilir. Kapitalizmin giderek artan bir şekilde mekânsal olarak kente yönelerek kendi mantığını dikte ettiği bu aşamada mekânın kendisini metalaştırmakta, kapitalizm büyümektedir (Lefebvre, 1991; Şengül, 2001b). Bu süreçte "sömürü", "yabanclaşma" ve "metafetişizm" gibi olguların da ortaya çıktı̆̆ görülmüş̧ür.

Gelişme ve yavaşlık tipik olarak birlikte yürümese de ekonomik anlamda kalkınma ve yavaşlık pek çok yer için oldukça elverişli görünmektedir (Servon ve Pink, 2015). Halfeti örneğinde yörenin yapısına uygun olmayan yeni otel binalarının yapılması, turistik tekne turlarında yüksek sesli ve popüler müzik yayını; Yenipazar örneğinde Belediye Başkanı değişimiyle birlikte kültürel mirasla ilgili çalışmaların seyrinin değişmesi ve bazı kazanımların kaybı, Seferihisar'ın yanı sıra, Akyaka'da yoğun trafik, motorlu tekne gezileri; Halfeti'de de konaklama ve yemek hizmetlerinde kitle turizmine yakınlaşan uygulamalar (Çıtak, 2016); Perşembe ve Seferihisar örneklerinde balık çiftlikleri (Özmen vd., 2017); Gökçeada'da nüfus artışı ve yapılaşmadaki artış (Erdoğan, 2016); Vize'de "İstanbullaşma" riski Ergüven (2011, s. 209) hareketin sürdürülebilirliğiyle ilgili olarak dikkat edilmesi gereken başlıca konulardandır.

İyi uygulama örneği bakımından İspanya'da sakin şehirlerin küreselleşme süreci içinde yerel unsurların korunduğu, diğer bir deyişle küyerel (glocal) bir nitelik taşıdığı tartışılmaktadır. Bu anlayış, neoliberal bir gündemle belirlenen, kalkınmanın gelişmeye eşit olarak görüldüğü işletme temelli anlayışa karşı direnirken, sakinlerine öncelik tanır (Servon ve Pink, 2015). Özmen vd., (2017) Taraklı'da konut yapımında (TOKİ) ilçenin kültürel dokusuna uygun diş cephe kullanımı ve kat sayısının sınırlı tutulmasına dikkat çekmiştir.

\section{Sonuç}

Araştırma kapsamında sakin şehir hareketinin mevcut ekonomik sistemin işleyişi içinde nasıl bir alternatif sunduğu ve bu sistem içinde sürdürülebilirliği araştırılmıştır. En önemli paydaşlar olup sürecin uygulayıcısı konumundaki kuruluşlarla; süreçten doğrudan etkilenen yerel halkla gerçekleştirilen mülakat ve anket sonuçları paralellik göstermektedir. Dünya'da ve Türkiye'de sa- 
kin şehir hareketi kapsamında çeşitli alanlarda öne çıkan, iyi uygulama örnekleri bulunmaktadır. Turizmin gelişmesi, ilçenin ve ürünlerinin markalaştırılması ve tanıtımı, kültürel mirasın, geleneklerin ve mimari dokunun korunması ve küreselleşirken yerel değerleri koruyan bir yaklaşımın geliştirilmesi bakımından sakin şehirler önemli bir işlev görmektedir. Seferihisar örneğinde, sakin şehir süreci ile birlikte turizmin gelişmesi ve yerel kalkınmanın sağlanması konusunda genel olarak olumlu görüş hâkimdir. Üretici birliklerinin geliştirilmesi ve turizmin ilçe ekonomisini canlandırmasıyla birlikte "kadınlar", "turizmle uğraşanlar" ve "esnaf" ilçede en önemli düzeyde gelir artışı sağlayan toplumsal sinfflar olmuştur.

Olumlu kazanımların ve uygulamaların yanı sıra ilçede hareketin sürdürülebilirliği açısından dikkat edilmesi gereken konular bulunmaktadır. Sermaye ilçede etkisini arttırırken, kentsel dönüşüm hız kazanmış, yeşil alanlar ve mandalina bahçelerinde yapılaşma sonucu bu alanlar azalmıştır. Sakin şehir unvanı küresel kapitalizm karşısında tam olarak bir kalkan olmayı başaramamış, adeta bir mıknatıs gibi kentsel sorunların kentlilerle birlikte ilçeye taşınmasına neden olmuştur. Çarpık yapılaşmanın yanı sıra, nüfus artışı, soylulaşma, pahalılığın artması, yerel halkın yabancılaşması, yerel halk arasındaki gelir farklılıklarının ve rekabetin artması; toplumsal kabul, kalkınma, çevre, katılımcılık ve sosyal-kültürel politikalar konusunda belirli bir sınırda olan oranlar uygulamada sorunların varlığına işaret etmektedir. Felsefenin benimsenmesi, halkın katılımının ve işbirliğinin artması ihtiyacı, Belediye Başkanının değişmesi durumunda uygulamaların gerilemesi riski, Türkiye örneğinde sakin şehirlerde sürdürülebilirliği tehdit eden konulardan bazılarıdır (Çıtak, 2016; Özmen, vd., 2017).

İlk olarak, toplumsal kabulü sağlamak için sakin şehir uygulamalarında eğitim düzeyi yüksek olmayan kesimlerin de dahil olacağı, toplumsal faydayı arttıracak nitelikteki uygulamalar hayata geçirilmelidir. Rekabet ortamı yerine ilçe mahalleleri arasında dayanışmanın sağlanması için olumsuz görüşteki kişilerin görüşleri alınmalı, ihtiyaç analizi çalışmaları doğrultusunda destekler sağlanmalıdır.

İkinci olarak, ekonomik hareketlilik ve iş olanaklarından yararlanan kesimler olsa da, gençler için istihdam olanaklarındaki sınırlılık gençlerin ilçeden göç etmesi ve ilçe nüfusunun yaş ortalamasının yükselmesi ile sonuçlanabilir. Genç bireyler için bu sınırlılıklar ortadan kaldırılarak, uygulamalara dahil edilmeleri sağlanmalıdır. Sorunlara yönelik çözüm önerilerinin geliştirilmesi konusunda yerel yönetime önemli bir görev düşmektedir. 
Üçüncü olarak, ekonomik büyümeye olan inancın sorgulandığı günümüzde çevrenin ve doğal kaynakların göz önünde bulundurulduğu ekolojik bir gelişme anlayışı aranmaktadır. Bu süreçte geliştirilen alternatiflerden birisi olan sakin şehir hareketinin Seferihisar örneğinde sunulan ilkelerle tam olarak uyumlu işlemediği görülmektedir. Bu anlamda gerek yerelde gerekse ulusal düzeyde politika yapma süreçlerinin sakin şehir ilkeleriyle eşleşmediği düşünülmektedir. Hâlihazırda bir nüfus dengesine, refah düzeyine ve alt yapı koşullarına sahip Avrupa ülkelerinde kavramın uygulanabilirliğinin daha kolay olacağı ve sürdürülebilirliğinin sağlanmasının daha başarılı olabileceği söylenebilir.

Dördüncü ve son olarak, neoliberal ekonomik sistem içinde sakin şehir kavramının da metalaşarak ilçe örneğinde kitlesel turizmi teşvik eden bir "pazarlama stratejisi" haline geldiği görülmektedir. Sakin şehir unvanına sahip olan ilçenin turizm politikaları yeniden gözden geçirilmelidir. Seferihisar örneğinde Daly (1990; 1991)'in belirttiği gibi niceliktense niteliksel olarak gelişime önem veren "yumuşak büyüme" (soft growth) modeli olarak yerel dokuya uygun nitelikte bir turizm anlayışı benimsenmelidir. Bu doğrultuda, yavaş turizm veya eko-turizm gibi sürdürülebilir uygulamalara ihtiyaç vardır. Sakin şehir uygulamalarının, sürdürülebilirlik konusunda tartışılan konuları ilçeler örneğinde iyileştirilmesi durumunda bu gelişme anlayışının yaygınlaşmasına katkı sağlayabileceği düşünülmektedir.

Bu araştırma Seferihisar ilçesi ile sınırlı olup, gelecek araştırmalarda farklı ilçe örnekleri üzerinden karşılaştırmalı çalışmalar yapılması, boylamsal çalışmalara yer verilmesi hareketin uzun vadeli toplumsal etkilerini belirlemek açısından oldukça faydalı olacaktır. Türkiye'de halen güncel bir konu olan sakin şehirlerle ilgili "kadınların güçlenmesi", "yeni kuşak gençler", "sonradan yerleşen kişilerin sınıfsal konumu ve sosyal tabakalaşma", "sosyal uyum", “yoksulluk", “komşuluk ilişkileri", "yaşam kalitesi” yeni çalışmalar için alana katkı sağlayacak konulardan bazılarıdır. İleriki yıllarda tekrarlanabilecek olan çalışmalarla hareketin etkileri ve ortaya çıkarttığı değişiklikler daha uzun vadeli olarak incelenebilecektir. 


\title{
Extended Abstract
}

\author{
* \\ N. Beril Özer Tekin \\ ORCID: 0000-0002-1402-7891
}

This paper is based on the results of my Ph.D. research (conducted between 2015 - 2018); "Cittaslow Movement and Sustainability in Seferihisar Turkey within the Process of Capitalism in Turkey". The majority of Cittaslow studies focus rather on local development, tourism, and urban policies, and few of them deal with the issue of sustainability from a critical perspective of capitalist production and accumulation regime. My study fills this gap and demonstrated that Cittaslow practice cannot be understood independently of capitalist production relations. In this respect, the main problem of this research is the Cittaslow movement that is offered as an approach alternative to the capitalist production system but the paper demonstrates that the movement should be rather conceived as integrated into the current economic system of development.

In this research, mixed methods were adopted and qualitative and quantitative research techniques were combined. In-depth interviews and questionnaire forms were developed in line with the purposes of the research. In this direction, the technique of face-to-face survey is applied to the local population, and the technique of the in-depth interview is applied to representatives of related institutions and elected neighborhood executives - mukhtars picked up from certain quarters with specific population according to the sampling methodology (Purposive sampling for the qualitative phase of the inquiry; proportional stratified sampling for quantitative phase of the inquiry). The data obtained from the questionnaire applied to 332 people selected through proportional stratified sampling "were processed through SPSS 21 (Statistical Package for Social Sciences) program; frequency and percentage values were calculated by using descriptive statistics, difference tests. The data acquired through a survey questionnaire conducted with local actors were analyzed from the perspective of the neo-Marxist urban studies approach. 
In the scope of the research, a total of 332 participants, 187 men, and 145 women, from 11 quarters of Seferihisar district, were reached. The local people, who are one of the most important stakeholders in Cittaslow practices, think of the development of tourism and local development together with the Cittaslow process in the district positively, while there are some negative opinions about the increase in population and the construction in agricultural areas. The projects carried out in the district, such as rehabilitation activities in the urban space and the support of the producer are among the activities supported by the local people since these applications have an increase in the income and quality of life for the local people. According to locals, the local community and development policies of the municipality in the district are very successful. According to the findings of the study, the most advantageous categories of the district after gaining the title of Cittaslow are employees of tourism (25\%); women (23\%), and tradesmen (14\%).

It is crucial to provide public attendance since the public is the most essential stakeholder in the Cittaslow movement. According to the results, 58\% of the participants have high social acceptance levels and $27 \%$ of the participants have low social acceptance levels. According to the results, it can be said that the title of Cittaslow and practices are socially accepted by more than half of the local people, but not by a quarter of the population. Besides, Payaml $(39 \%)$, and Mersinalanı (33\%) are the quarters below $50 \%$, with the least social participation on the Cittaslow concept in the district. To investigate the source of these differences between the participants, the distribution of neighborhoods according to educational status was analyzed. According to the calculated difference tests it was evaluated that the tendency to support the Cittaslow increased as the education level increased.

In the case of Seferihisar, which was articulated to the wheel of the capitalist economic system. The inevitable growth of the tourism industry could not have been prevented. The intense interest of the visitors and the increase in the popularity of the district with the title initiated the debate that the district is in danger of losing its characteristics. The Cittaslow initiative which is known as an alternative local development model has progressed with the development of the tourism sector in the case of Seferihisar. In this process, it should be considered to adopt the eco-tourism/slow tourism concept which is one of the most environmentally peaceful industries.

Neither the movement nor the local authorities could not resist the larger investments due to the lack of legal enforcement power to prevent mass tou- 
rism within the case. Tourism had become the most important economic source of the district and the tangerine gardens opened to zoning and construction. In some districts, the process of urban transformation had been continued, and the lands of the mandarin orchards were replaced by new houses or hotels. At this point, the title of Cittaslow, unlike the presumed name of a shield failed to be an alternative but became such a magnet that caused problems related to the big city in this case.

Besides the positive initiatives, several urban problems developed within the town, such as "increasing population", "urban sprawl", "increase in the construction of new buildings" and "environmental problems". The transformation of the districts had brought social, cultural, and economic changes for the people of the neighborhood, and the dynamic of neighborhood relations. The population growth together with the title caused impacts such as "alienation", "inflation", gentrification-displacement" and "social stratification" in the district. In this process, local people who settled in the district and faced people with higher incomes from the upper classes began to feel isolated, alienated, and marginalized among the current population. At this point, the factors which cause people to escape the metropolitan city life and migrate to smaller settlements such as Seferihisar, led paradoxically to the fact that the city itself became problematic similar to the metropolitan cities.

Finally, although Cittaslow has been posed as an alternative to the current capitalist economic system, urban space became commodified and Cittaslow has been instrumentalized in the marketing process. As a result, although the studied case provided good practice examples, there is some difficulty in the sustainability of the cittaslow movement in the context of the case.

\section{Kaynakça/References}

Akdoğan, Ç. (2017). Destinasyon markalama bağlamında yavaş şehir (cittaslow) hareketi üzerine genel bir değerlendirme. Journal of International Scientific Researches, 379-390. https://doi.org/10.21733/ibad.370202

Andarabi, F. F. (2012). Cittaslow markasma sahip şehirlerde yerel halkm turizme yaklaşımı üzerine bir analiz: Seferihisar örneği. (Yüksek lisans tezi). Yükseköğretim Tez Merkezi. (317066)

Arikan, İ., Dündar, A. \& Edlinger, L. S. (2015). Is cittaslow an effective model in destination development for sustainable tourism? a case study in Austria, Proceedings of the International Conference. Sciencein Technology-SCinTE, Nowember 5-7, Athens, Greece, 22-25.

Atvur, S. (2014). 21. Yüzyllda değişen toplumsal hareketler. Praksis Dört Aylk Sosyal Bilimler Dergisi, 34, 13-39. 
Beatley, T. (2005). Native to nowhere: sustainable home and community in a global age. Washington DC: Island Press.

Bell, D. \& Jayne, M. (2006). Small cities: Urban experience beyond the metropolis. New York: Routledge.

Castells, M. (1983). The city and the grassroots: a cross-cultural theory of urban social movements. Berkeley and Los Angeles: University of California Press.

Castells, M. (2002). Urban sociology in the twentyfirst century. I. Susser (Der.). The Castells reader on cities and social theory içinde (ss. 9-19). Oxford: Blackwell.

Cittaslow International. (t.y.). Home page. 3 Eylül 2020 tarihinde https://www.cittaslow.org/ adresinden erişildi.

Cittaslow Türkiye. (t.y.). Ana sayfa. 4 Eylül 2020 tarihinde https://cittaslowturkiye.org/ adresinden erişildi.

Cohen, J. L. \& Arato, A. (1992). Civil society and political theory. Cambridge, MA: MIT Press.

Çakıd, A. C., Yenipınar, U. ve Benli , S. (2014). Yavaş şehir hareketi: Seferihisar halkının tutum ve algilarn ile yaşam doyumları. Seyahat ve Otel Issletmeciliği Dergisil Journal of Travel and Hospitality Management 11 (3), 26-41. 10 Eylül 2016 tarihinde https://dergipark.org.tr/tr/download/article-file/117639 adresinden erişildi.

Çayır, K. (1999). Toplumsal sahnenin yeni aktörleri: yeni sosyal hareketler. İstanbul: Kaknüs Yayınları.

Çerçi, A. (2013). Destinasyon markalama ve yavaş şehir Seferihisar'm destinasyon marka imajı. (Yüksek lisans tezi). Yükseköğretim Tez Merkezi. (339056).

Çıtak, Ş. Ö. (2016). Sakin şehirler hızlı turistler, İnsan ve Toplum Bilimleri Araştırmalarn Dergisi, 5(8), 2692-2706. doi: 10.15869/itobiad.281857

Çiçek, M., Ulu, S. \& Uslay, C. (2019). The impact of the slow city movement on place authenticity, entrepreneurial opportunity, and economic development.Journal of Macromarketing, 39(4), 400-414. https://doi.org/10.1177/0276146719882767

Daly, H. E. (1990). Sustainable growth: an impossibility theorem. Development, 3(4), 45-48. 1 Temmuz 2021 tarihinde https://is.muni.cz/el/1423/jaro2013/MEB415/um/Daly_1990_4547.pdf adresinden ulaşıld.

Daly, H. E. (1991). Sustainable growth: a bad oxymoron, Environment and Carcinogenic Reviews, 8(2), 401-407. doi:10.1080/10590509009373395

Değirmenci, İ. ve Sarıbıyık, M. (2015). Tarihi mekânlarda sürdürülebilirlik bağlamında cittaslow hareketi: Taraklı örneği. 2. International Sustainable Buildings Symposium, 28-30 Mayıs, Ankara, 612-620. http:/www.isbs2015.gazi.edu.tr/belgeler/bildiriler/612-620.pdf

Ekincek, S., \& Aksöz, E., O. (2016). Evaluation of the cittaslow administrators to the process of cittaslow participation and sustainability. Anadolu Üniversitesi Sosyal Bilimler Dergisi, 16(4), 171-189. https://doi.org/10.18037/ausbd.415574

Erbaş H. ve Soydemir, P. (2011). Sermaye hareketleri ve küresel kent olma yolunda İstanbullar. S. Şahinkaya ve N. İ. Ertuğrul (Der.), Bilsay Kuruç'a armağan içinde (ss. 635-677). Ankara: Mülkiyeliler Birliği Yayınları.

Erdoğan, M. (2016). Local community perception towards slow city: Gokçeada sample. Asian Social Science, 12 (5), 241-246. doi:10.5539/ass.v12n5p241

Eriksen, T. H. (2001). Small places big issues. London: Pluto Press. 
Ergüven, M. H. (2011). Cittaslow - yaşamaya değer şehirlerin uluslararası birliği: Vize örneği. Organizasyon ve Yönetim Bilimleri Dergisi, 3(2), 201-210. 1 Haziran 2021 tarihinde https://dergipark.org.tr/en/pub/oybd/issue/16338/171061 adresinden erişildi.

Faaliyet Raporları. t.y. Seferihisar Belediyesi Web Sitesi. 1 Ağustos 2021 tarihinde http://seferihisar.bel.tr/faaliyet-raporlari/ adresinden erişildi.

Giddens, A. (1994). Modernliğin sonuçları. (E. Kuşdil, Çev.). İstanbul: Ayrıntı Yayınları. (Orijinal eserin yayın tarihi 1990).

Grzelak-Kostulska, E., Hołowiecka, B. \& Kwiatkowski, G. (2011). Cittaslow international network: an example of a globalization idea?. P. Mácha \& T. Drobík (Der.), The scale of globalization think globally, act locally, change individually in the 21st century içinde (ss. 186-192). Ostrava: University of Ostrava.

Habermas, J. (1981). New social movements. Télos, (49), 33-37. doi: 10.3817/0981049033

Harvey, D. (2003). Postmodernliğin durumu (3. bs.). (S. Savran, Çev.). İstanbul: Metis Yayınları.

Hekimci, F. (2014). Sürdürülebilir bir yerel kalkınma modeli: yavaş şehirler ve ekoturizm, kalkınmada anahtar verimlilik, Anahtar, 306, 1 Haziran 2016 tarihinde https://anahtar.sanayi.gov.tr/tr/news/surdurulebilir-bir-yerel-kalkinma-modeli-yavassehirler-ve-ekoturizm/1772 adresinden erişildi.

Heitmann, S., Robinson, P., \& Povey, G. (2011). Slow food, slow cities and slow tourism. P. Robinson, S. Heitmann, veP. Dieke(Der.), Research themes for tourism içinde(ss.114-127). UK: CAB International.

Honore, C. (2008). Yavaş. (E. Gür, Çev.). İstanbul: Alfa Yayınevi.

Kavoulakos, K. I. (2006). The emergence, development and limits of the alternative strategy of the urban movements in Germany. City 10(3), 343-354. https://doi.org/10.1080/13604810600982370

Keat, R. ve Urry, J. (1994). Bilim olarak sosyal teori. Ankara: İmge Kitabevi.

Keskin, E. B., (2012). Sürdürülebilir kent kavramına farklı bir bakış: yavaş şehirler (cittaslow). Paradoks Ekonomi, Sosyoloji ve Politika Dergisi, 8(1), 81-99. 5 Arallk 2016 tarihinde https://dergipark.org.tr/en/pub/paradoks/issue/16354/171237 adresinden erişildi.

Knox, P. L. (2005). Creating ordinary places: Slow cities in a fast world. Journal of Urban Design, 10(1), 1-11. https://doi.org/10.1080/13574800500062221

Kundera, M. (1996). Slowness. London: Faber and Faber Limited.

Kümbetoğlu, B. (2005). Sosyolojide ve antropolojide niteliksel yöntem ve araştırma. İstanbul: Bağlam Yayıncilik.

Lefebvre, H. (1991). The production of space. (D. Nicholso. Çev.). Oxford: Blackwell.

Mayer, H. \& Knox, P. L. (2006). Slow cities: sustainable places in a fast world. Journal of Urban Affairs, 28(4), 321-334. doi: 10.1111/j.1467-9906.2006.00298.x

Mayer H. \& Knox P.L. (2009). Pace of life and quality of life: the slow city charter. Sirgy M.J., Phillips R., Rahtz D.R. (Der.). Community quality-of-life indicators: best cases III içinde (ss. 2140). Dordrecht: Springer. https://doi.org/10.1007/978-90-481-2257-8_2

McCann, E. J. (2008). Expertise, truth, and urban policy mobilities: global circuits of knowledge in the development of Vancouver, Canada's 'four pillar' drug strategy. Environment and Planning A 40(4), 885-904. doi:10.1068/a38456 
Merrifield, A. (2012). Metromarksizm şehrin Marksist bir hikâyesi, (N. Ünver, Çev.). Ankara: Phoenix Yayınları.

Mutdoğan, S. (2015). Cittaslow movement as a tool for sustainable communities in Turkey. S.A. Wilson (Der.), Identity, culture and the politics of community development içinde (ss. 143165). UK: Cambridge Scholars.

Nakip, M. (2013). Pazarlama araştırmaları. Ankara: Seçkin Yayınalık.

Nilsson, J. H., Svärd A., Widarsson Å. ve Wirell T. (2011). Cittáslow ecogastronomic heritage as a tool for destination development. Current Issues in Tourism, 14(4), 373-386. doi: 10.1080/13683500.2010.511709

Offe, C. (1985). New Social Movements: Challenging the Boundaries of Institutional Politics. Social Research, 52 (4), 817-868. 1 Ocak 2017 tarihinde https://www.jstor.org/stable/40970399 adresinden erişildi.

Özür Karakaş, N., (2016). Sakin şehir/cittaslow hareketi ve yerleşme coğrafyası, SDÜ Fen Edebiyat Fakültesi Sosyal Bilimler Dergisi, (37), 151-179. 2 Haziran 2017 tarihinde https://dergipark.org.tr/en/pub/sufesosbil/issue/17215/179761 adresinden erişildi.

Öztürk, S. (2012). Small towns reshaping their urban planing policies joining in the cittaslow international network: the case of Seferihisar in Turkey. (Yüksek lisans tezi). Yükseköğretim Tez Merkezi. 321063.

Pink, S. (2009). Urban social movements and small places, Taylor and Francis Online, 13(4), 451465. https://doi.org/10.1080/13604810903298557

Radstorm, S. (2011). A place sustainin framework for local urban identity: an introduction and history of cittaslow. Italian Journal of Planning Practice, 1(1), 90-113. 5 Aralı 2016 tarihinde https:/www.cittaslow.org/sites/default/files/content/news/files/7864/_an_introduction_an d_history_of_cittaslow.pdf adresinden erişildi.

Sayar, K. (2018). Yavaşla. İstanbul: Kapı Yayınları.

Semmens, J. \& Freeman, C. (2012). The value of cittaslow as an approach to local sustainable development: a New Zealand perspective. International Planning Studies, 17(4), 353-375. doi: 10.1080/13563475.2012.726851

Servon, L.\&Pink, S. (2015). Cittaslow: going glocal in Spain, Journal Of Urban Affairs. 37(3), 327340.

Sırım, V. (2012). Çevreyle bütünleşmiş bir yerel yönetim örneği olarak sakin şehir hareketi ve Türkiye'nin potansiyeli. Tarih- Kültür ve Sanat Araştırmalarn Dergisi. 1(4), 119-171. doi: 10.7596/taksad.v1i4

Slow. (t.y.). Ana sayfa. 2 Ekim 2017 tarihinde: http://www.carlhonore.com adresinden erişildi.

Slow Food International. (t.y.). Our history. 3 Eylül 2020 tarihinde https://www.slowfood.com/about-us/our-history/adresinden erişildi.

Steele, W. (2012). Do weneed a slow housing movement?. Housing Theory and Society, 29/2, 172189. 2 Haziran $2016 \quad$ tarihinde https://www.tandfonline.com/doi/abs/10.1080/14036096.2011.641260 adresinden erişildi.

Sungur, Z. (2013). Türkiye'nin sakin şehirlerindeki kadın girişimciliğine sosyolojik bir bakış. International Conference On Eurasian Economies SESSION3C: Girişimcilik, 1 Kasım 2015 tarihinde http://www.avekon.org/papers/786.pdf adresinden erişildi. 
Şahin, İ. ve Kutlu, S., Z., (2014). Cittaslow: sürdürülebilir kalkınma ekseninde bir değerlendirme. Journal of Tourism and Gastronomy Studies, 2(1), 55-63. 1 Ekim 2016 tarihinde https://www.jotags.org/Articles/2014_vol2_issue1/2014_vol2_issue1_article7.pdf adresinden erişildi.

Şahinkaya S. (2010). Bir yerel kalkınma modeli: cittáslow ve Seferihisar üzerine değerlendirmeler. $\quad 16 \quad$ Ekim $\quad 2015 \quad$ tarihinde http://www.bagimsizsosyalbilimciler.org/Yazilar_Uye/SahinTem10.pdf adresinden erişildi.

Şengül, H. T. (2001a). Kentsel çelişki ve siyaset: kapitalist kentleşme süreçleri üzerine yazılar. İstanbul: Wald Demokrasi Kitaplığı.

Şengül, H. T. (2001b). Sınıf mücadelesi ve kent mekânı. Praksis Dergisi (2), 9-31. 10 Haziran 2018 tarihinde http://www.praksis.org/tumsayilar/sayi-2-kentler-ve-kapitalizm/ adresinden erişildi.

Şengür, Ş. ve Atabeyoğlu, Ö. (2018). Slow city movement: a case study Perşembe-Ordu. Kastamonu University Journal of Engineering and Sciences, 4(1), 25-33. 2 Haziran 2019 tarihinde https://dergipark.org.tr/en/pub/kastamonujes/issue/41743/440599 adresinden erişildi.

Toffler, A. (2006). Şok, İstanbul: Koridor Yayıncllk.

Touraine A. (1992). Beyond social movements?. Theory, Culture $\mathcal{E}$ Society, 9(1), 125-145. doi:10.1177/026327692009001007

Üstündağll, E., Baybars, M. \& Güzeloğlu, E., B. (2015). Collaborative sustainability: analyzing economic and social outcomes in the context of cittaslow. Business and Economics Research Journal, 6(1), 125-144.

Virgilio, P. (1998). Hiz ve politika. İstanbul: Metis Yayınları.

Yüksel Özmen, Ş., Birsen, H, ve Birsen, Ö. (2017). Sakin şehir Yalvaç örneğinde sürdürülebilirlik, sakin şehirler ve toplumsal katılım, Akademia Sosyal Bilimler Dergisi. 1 (3), 140-158. 1 Haziran 2021 tarihinde https:/dergipark.org.tr/en/download/article-file/1263315 adresinden erişildi. 